10.2478/v10103-011-0013-3

\title{
The Ecological and Ethical Consumption Development Prospects in Poland Compared with the Western European Countries
}

\begin{abstract}
An overview of the Western European literature shows that one of the most distinct trends in consumption that has been noted in the recent years is globally increasing environmental and social awareness. The issue of consumers' behaviours and attitudes towards "socially responsible products" has been gaining importance in Polish economy as well. This article evaluates the development prospects of ethical and ecological consumption in Poland visà-vis Western European countries. The comparative analysis being part of the article utilizes primary sources of information, i.e. interviews with a representative sample of Polish adults, as well as secondary sources of information. A factor analysis or, more precisely, a principal component analysis, allowed dividing Polish consumers into groups that were typologically homogeneous in respect of their sensitivity to various aspects of business ethics and ecology.
\end{abstract}

\section{Introduction}

The 1970s were a decade when the unfavourable and massive repercussions of the post-war growth and economic upturn emerged for the first time. A distinctly deteriorating quality of the natural environment gave rise to

\footnotetext{
* Ph. D., Technical University of Łódź
} 
many environmental movements that in the last two or three decades of the $20^{\text {th }}$ c. century managed to raise the environmental and ethical awareness of the general public and succeeded in building their principles into everyday human behaviour, mainly into consumer attitudes (Bywalec 2001, p. 138).

It is worth knowing that the gradual environmental degradation, the shrinking of non-renewable resources, the falling quality of life and increasingly common cases of unethical behaviour were all directly or indirectly arising from snowballing consumption. It is therefore rational to assume that these unfavourable processes will not stop unless consumption patterns are appropriately modified. This awareness makes the ecologization of consumption a more and more frequent subject of debates, for it is viewed as a possibility of reversing the above adverse trends. Czesław Bywalec indicates that the ecologization of consumption should comprise:

- rational use of consumer goods,

- limiting the consumption of goods that involve large amounts of scarce, nonrenewable resources,

- buying and consuming goods that generate limited amounts of postconsumer waste,

- use of environmentally-friendly goods, such as artificial leather, artificial protein, imitation wood and glass,

- consumption of goods that are not tainted by slave-like and low-paid labour or inhumane animal farming.

Because ethics is increasingly often added to the range of purely ecological subjects, ethical consumerism that refers to buying ethical products, i.e. those made without harm to or exploitation of humans, animals or the natural environment is discussed more and more frequently. Ethical consumerism may take the following forms:

- Positive buying - favouring ethical products and businesses that operate on principles based on benefit for the greater good rather than self-interest,

- Moral boycott - avoidance of particular products, services and companies that are deemed to follow unethical practices (Global Lifestyle... 2008).

2. Green consumption and ethical consumption as an expression of changing consumer behaviour - differences between the Western and Eastern European countries

Eco-consumption, sometimes called green consumption, is a very positive trend that helps rationalise consumption and the entire economy. Ecological 
movements, frequently turning into consumer movements, lay an increasingly strong stress also on the ethical aspect of consumption. This attitude additionally contributes to the growing importance of the notion of ethical consumption.

Even though the worldwide impacts of these tendencies are still fairly weak and, as shown by research, price and quality continue to be the main criteria behind purchasing decisions, it is also becoming quite obvious that consumers pay more and more attention to the ways manufacturers and providers handle their business. Consumers' needs and values have changed and they will keep changing in the future. Attitudes generate needs that form buying patterns. A growing segment of consumers, particularly in the developed countries, are wealthy enough to be concerned with more than basic product characteristics, i.e. with quality, timeliness and the environmental and social dimensions of production processes. In response to these changes, the business sector has been developing new non-functional features for brand differentiation, such as environmental or social qualities of the manufacturing, transportation and marketing processes (Adhikari, Yamamoto 2007, p. 205). We can observe a growing number of companies engaging in CSR activities. Important question seems to be how important is this engagement to global consumers today?

According to Nielsen's recent Global Online Survey on Business Ethics and Fair Trade, it is very important. The survey, which polled 28,253 online consumers in 51 markets, revealed that over 80 per cent of the world's Internet users think it is very or somewhat important that companies implement programs to improve the environment (88\%) and/or society (84\%) (Corporate Ethics... 2008).

Looking at Western and Eastern Europeans we can observe that they hold similar views on this matter, with an average of eight out of ten consumers believing it is important or very important for companies to contribute in some way to the environment and/or to society ( $85 \%$ and $78 \%$ respectively).

However, when concrete purchasing decisions are analysed instead of consumers' very broad declarations, then differences between Western and Eastern Europe become quite distinct.

Eight out of ten $(79 \%)$ Western Europeans feel it is important to know that the products they purchase have little impact on the environment, with 74 per cent wanting to know the product was made according to ethical labour standards. Eastern Europeans are the least concerned (54\%) about whether the product they purchase has negatively impacted workers, though three quarters (76\%) feel it is important to know the product's environmental footprint is minimal.

The sources of the differences should be sought in that fact that the Western European consumers are both wealthier and more sensitive to 
ecological and ethical issues. In Western Europe, an important role was played by active NGOs that frequently turned into consumer movements exerting strong influence on firms and concerns. In the CEE countries, this type of public activity is only starting to emerge. In Western Europe, more and more attention is given to a particular market segment of consumers interested in sustainable living and "green" ecological initiatives. This group is called LOHAS consumers ${ }^{1}$. LOHAS has been identified as an emerging market in the USA and has been the subject of significant social and market research. This population segment represents consumers who are well-informed, are strong advocates for sustainable businesses, products and services and the markets they represent keep spreading throughout the globe. LOHAS matter as their numbers are set to grow in coming years. They are vocal supporters of innovative and sustainable products and services, and are opinion leaders that continue to shape sustainability from the public's perspective. The LOHAS consumers are seeking goods and services that support their desire for health, environment, protection, social justice, personal development and sustainable living. Although LOHAS consumers are characteristic of the developed countries, mainly of the USA and Western Europe, which is clearly confirmed by research undertaken in the United States of America, Belgium, France, Germany, Italy, Netherlands, Portugal, Spain, United Kingdom, Australia and Japan, they are gradually becoming something more than a developed world trend. There is also anecdotal evidence that a number of other countries have been identified that contain LOHAS consumers and markets, for instance China and South Korea, South East Asia, Brazil and India (see Chart 1).

\footnotetext{
${ }^{1}$ LOHAS stands for Lifestyles of Health \& Sustainability, a term used to describe a type of consumer and the marketplace these consumers participate in. They seek out goods and services focused on health, the environment, social justice, personal development and sustainable living. The term LOHAS was coined in 1999 by Conscious Media, founders of the LOHAS Journal in the USA. Conscious Media built on the research into Cultural Creatives, providing a more in-depth market perspective of this emerging social phenomenon. Nowadays LOHAS is commonly used acronym to describe the market place for these types of products and services and the customerswho shop in them. See: Global Lifestyle of Health and Sustainability. An overview ..., op.cit. p. 3-6.
} 


\section{Graph 1. LOHAS markets identified globally}

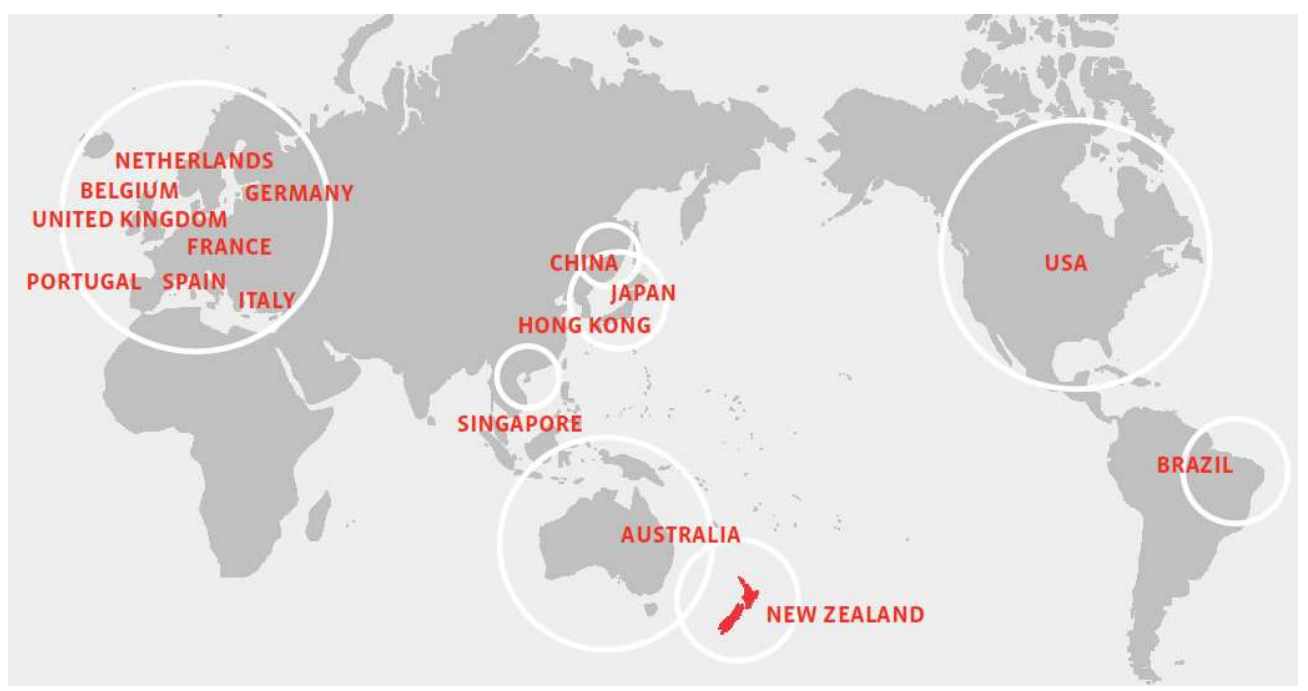

Source: Global Lifestyle of Health and Sustainability. An overview on the growing global market ..., op.cit. p. 10.

The LOHAS markets have been measured in Australia and the USA. In 2007 they were estimated at AUS $\$ 12$ billion annually in Australia ${ }^{2}$ and at US $\$ 209$ billion annually in the USA ${ }^{3}$. Western Europe has not been measured yet, but based on the green market percentage relative to the overall economies of both Australia and the USA it has been conservatively estimated at $€ 260$ billion (Global Lifestyle...2008. p. 16). In Eastern European this trend is not that strong, but globalization processes and the pace of economic growth in some countries in the region can be expected to make it stronger in years ahead.

It should not be surprising therefore that the support for Fairtrade products nowadays is also largely concentrated in Western Europe, where the European Commission prepared the 'Memo on Alternative Trade' as early as 1994. With governments across Europe committing to Fairtrade regulation, European awareness of the existence of such products is the highest in the world. Nielsen research shows that 84 per cent of Western Europeans are aware of Fairtrade products vis-à-vis the global average of 49 per cent. Compared with Western

\footnotetext{
${ }^{2}$ Data taken from Mobium Group in Australia - Living LOHAS report 2007 @.

${ }^{3}$ Data taken from NMI - LOHAS in the USA 2007тM and Understanding the European LOHAS Markets ${ }^{\mathrm{TM}}$ ().
} 
Europe, only around a third (30\%) of Eastern European consumers claim to be aware of Fairtrade products (Corporate Ethics... 2008).

\section{Eco- and ethical consumerism in Poland compared with Western European countries.}

Consumption has become a dominant phenomenon of our world. An opinion exists that we are witnessing today the biggest consumer boom ever known in such a short time. It is not occurring, as might be supposed, in the long-rich countries, but in certain developing and transition countries frequently termed as new consumer ${ }^{4}$ countries. Today's new consumers are consuming as fast and as variously as they can, although most still have a very long way to go before catching up with North American and West European lifestyles. All the new consumers have reached a level of affluence where they can satisfy not only every basic need but some luxuries as well. All too often, however, today's headlong consumption - whether in new consumer countries or, more pertinently, in the long-rich countries - means environmental problems such as grand-scale pollution, waste mountains, energy shortages, land degradation, water deficits, even climate upheavals. Of course, such environmental troubles have arisen chiefly in the so-called developed countries, the ones that have enjoyed fattest-cat lifestyles for decades. The new consumers are doing no more than follow a well-beaten path (Myers N., Kent J. 2004, p. 4). Based on the basic criteria (a new-consumer country has had a record of fast economic growth, generally averaging $5 \%$ per year for 10 years together with a population of at least 20 million people) 20 new consumer countries were identified (see table).

\footnotetext{
${ }^{4}$ The new consumers are defined as people within an average of four-member households who possess purchasing power of at least US $\$ 10,000$ per year, or at least US $\$ 2500$ per person. These cut off figures may seem a trifle arbitrary, but they are no more so than a parallel categorization in developed countries. PPP of US $\$ 10,000$ per household is a minimum estimate, and most new consumers possess purchasing power way higher, often several times more. The basic figures are used here because they mark the rough stage when people start to engage in a distinctly middleclass lifestyle. As people climb the income ladder, they buy televisions, refrigerators, washing machines, air conditioners, and electronics such as hi-fi equipment and personal computers, among other perquisites of an affluent lifestyle. They shift to a diet strongly based on meat, especially grain-fed meat. They consume large amounts of water, not only in their homes but via grainland irrigation. As they climb still farther up the income ladder, they buy cars, often the fancier models. For sure, the pattern of consumption varies from country to country, just as the amount of consumption varies according to the amount of income and spending power. But the picture above serves to reflect the situation in new-consumer countries as a whole. More in Myers, N.; Kent 2004. pp. 8-10.
} 
1Poland is one of the three Eastern European countries (together with the Ukraine and Russia) that have been included in this group. All the other countries in the region are either too small in population terms or too poor.

In analysing ecological and ethical consumption prospects in Poland, the following question seems to be crucial: what does actually drive the new consumers, especially insofar as their recent arrival may mean they have motivations different from their counterparts in the long-rich countries?

In the next sections of the article population attitudes towards socially responsible consumption in Poland being one of the new consumer countries and in the long-rich UK will be compared.

\section{Methodology}

Between 30 November and 8 December 2010, an Omnibus-type survey involving a representative sample of 981 adults living in Poland was conducted. The sample was compiled by the Public Opinion Research Centre (CBOS) in order to make sure that it is reliable and representative. The sample was drawn from the PESEL system. Face-to-face interviews were enhanced with the CAPI (Computer Assisted Personal Interviewing). To ensure that the Polish survey is comparable with those performed in Western Europe, it was referred to the UK survey that was conducted in the same period and used a similar sample of consumers. The UK figures were determined during the annual Ethical Shopping Survey performed by the Co-operative Bank. Total sample size was 1013 adults. Fieldwork was undertaken between 18th and 19th November 2010. The figures have been weighted and are representative of all UK adults (aged 18+) (Ethical Consumerism... 2010). Additionally the results of the 2010 Polish survey were compared with those obtained in the UK in 1999, 2007, and $2009^{5}$.

\footnotetext{
${ }^{5}$ 1,970 UK residents aged 15+interviewed face-to-face (MORI Omnibus) between 18-22 May 2000, see: Robert M Worcester,Ethical Consumerism Research conducted for the Co-operative Bank, May 2000.
} 
Table 2. Socio-demographic structure of Polish respondents

\begin{tabular}{|c|c|c|}
\hline & & $\%$ from $\mathrm{N}$ in the column \\
\hline \multirow[t]{2}{*}{ Gender } & Male & $47.6 \%$ \\
\hline & Female & $52.4 \%$ \\
\hline \multirow[t]{6}{*}{ Age } & 18-24 years & $13.6 \%$ \\
\hline & $25-34$ & $17.4 \%$ \\
\hline & $35-44$ & $14.6 \%$ \\
\hline & $45-54$ & $18.1 \%$ \\
\hline & $55-64$ & $18.1 \%$ \\
\hline & 65 years and older & $18.3 \%$ \\
\hline \multirow[t]{5}{*}{ Place of residence } & Rural areas & $37.6 \%$ \\
\hline & Town with population to 20,000 & $13.9 \%$ \\
\hline & $20,000-100,000$ & $20.0 \%$ \\
\hline & $101,000-500,000$ & $15.8 \%$ \\
\hline & 501,000 and more. & $12.7 \%$ \\
\hline \multirow[t]{4}{*}{ Education } & Elementary & $25.3 \%$ \\
\hline & Basic vocational & $25.7 \%$ \\
\hline & Secondary & $33.7 \%$ \\
\hline & Tertiary & $15.3 \%$ \\
\hline \multirow{8}{*}{$\begin{array}{l}\text { Socio-occupational group } \\
\text { Economically active }\end{array}$} & Managers, specialists with tertiary education & $17.4 \%$ \\
\hline & Middle-level personnel, technicians & $8.2 \%$ \\
\hline & Office and administrative personnel & $13.7 \%$ \\
\hline & Personnel in the service sector & $10.6 \%$ \\
\hline & Skilled workers & $23.2 \%$ \\
\hline & Unskilled workers & $11.2 \%$ \\
\hline & Farmers & $9.3 \%$ \\
\hline & Self-employed & $6.5 \%$ \\
\hline \multirow[t]{5}{*}{ Economically inactive } & Disability pensioners & $13.6 \%$ \\
\hline & Old-age pensioners & $44.1 \%$ \\
\hline & School-children and students & $14.0 \%$ \\
\hline & Unemployed & $17.4 \%$ \\
\hline & Housewives and others & $11.0 \%$ \\
\hline
\end{tabular}

Source: developed by the author. 
The British and Polish consumers' predisposition to ethical behaviours was measured using eight separate indicators. The studied periods were years 1999, 2007, 2009 and 2010 for the United Kingdom and 2010 for Poland. The results are shown on graph 1.

Comparing the Polish and British data we find that in some respects today's Poland represents the same level of ethical consumerism that the UK was at a decade ago. In 2010, a one-fourth of Polish consumers actively sought information about firms' behaviour, a proportion exactly the same as the percentage of UK residents in $1999^{6}$. A similar situation can be observed for Polish consumers avoiding a product or service on a company's behaviour in 2010. They accounted for $45 \%$ of the population, a share almost the same as the UK had 10 years ago.

For one category of attitudes Polish consumers were ranked much below British ones in both 1999 and 2010. Only 6\% of Polish consumers participated in an event or a campaign promoting responsible consumption or Fairtrade in the 12 months preceding the survey. The UK rates were $15 \%$ and $25 \%$ in 1999 and 2009 , respectively. A definitely smaller percentage of Polish consumers than of British ones recommended products of some company to friends or family members on account of the company's dedication to environmental protection or a local community (35\%), as the UK rates were 52\% in 1999 and $69 \%$ in 2010. Besides, a much smaller percentage of Poles declared that in the preceding 12 months they had bought a product for its being manufactured ethically, i.e. without damaging the environment or hurting human health or with respect for workers' rights. In 2010, this declaration was made by $35 \%$ of the surveyed Poles compared with more than half of UK consumers that stated the same already eleven years earlier. Within the next ten years their proportion increased to $60 \%$.

${ }^{6}$ In 2009, the percentage of individuals seeking information about firms' non-business activities increased to $38 \%$, but in the next 12 months it fell to $31 \%$. In the years $1999-2009$, UK citizens were more and more predisposed to ethical behaviour in all the analysed categories, but in 2009 the trend collapsed. Across almost all analysed indicators, between 2009 and 2010, UK consumers reported decreased predisposition to ethical behaviours. Supposedly, the reasons behind this change in attitudes were global crisis and slowing down economic growth in most Western European countries. Whether this was a temporary change caused by souring social mood or a more stable trend is difficult to say. 
Graph 1. Ethical behaviours in Poland and UK - \% of people undertaking the following at least once during the year

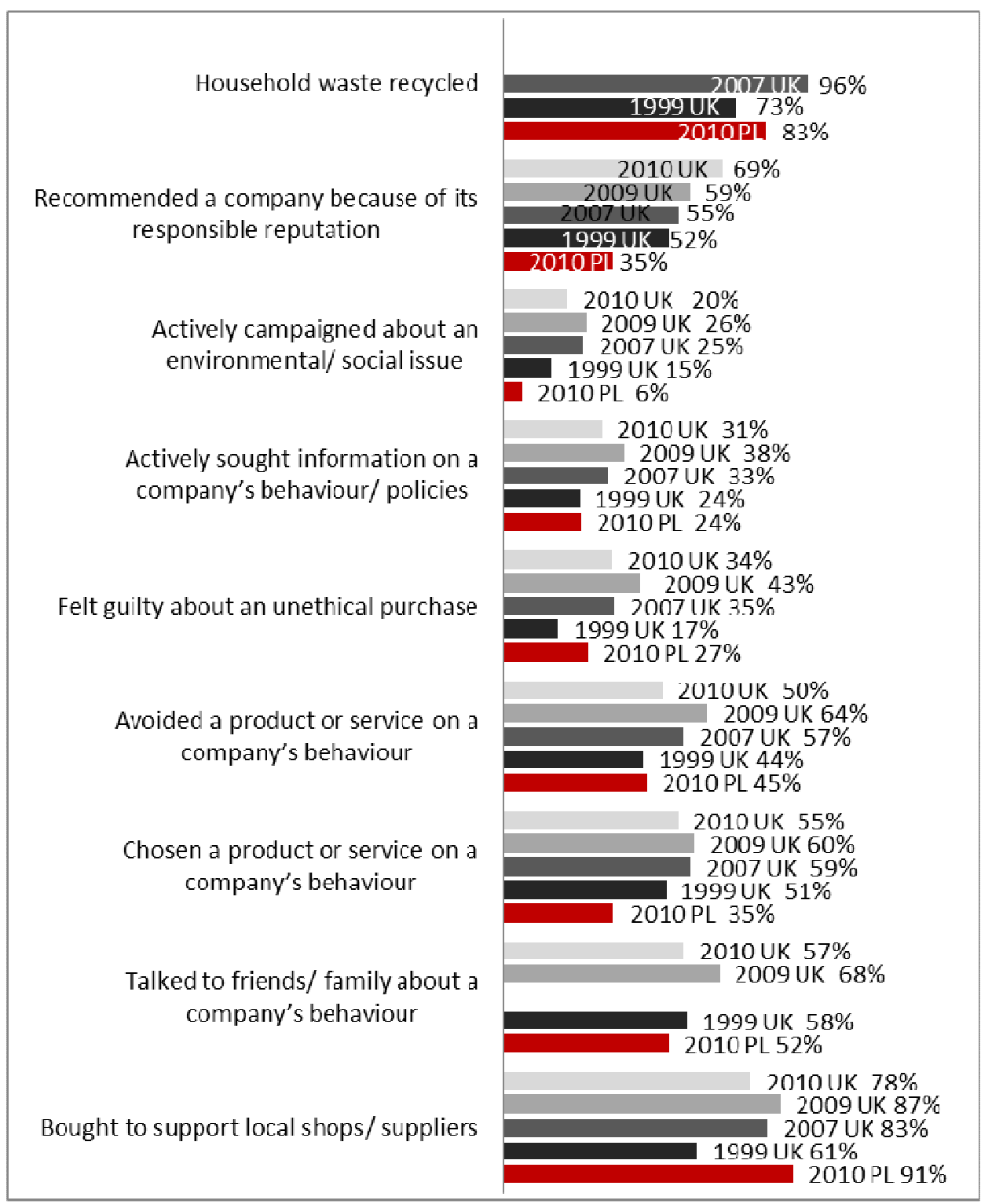

Source: developed by the author based on own research and the Ethical Consumerism Report 1999, 2007, 2009 and 2010. 
For one category of behaviours, though, Polish consumers ranked better than their British counterparts in both 1999 and 2010. Polish consumers are more inclined to support domestic producers and to do their shopping in local shops (91\%) than British ones (61\% and 78\% in 1999 and 2010, respectively). They also come out relatively well regarding household waste recycling, as 87 per cent of the population reported to recycle in the previous 12 months.

Another interesting comparison was made to contrast the degrees of consumers' conviction that their actions and attitudes could modify the way firms do their business. There were as many Polish consumers who definitely believed in their being able to influence the standards of business conduct as Britain had 10 years ago. Moreover, Polish consumers had stronger views. Only $8 \%$ of them had no opinion on that subject or could not clearly indicate where they were on the scale, compared with over $20 \%$ of British consumers (see Graph 2)

Graph 2. Empowered consumers - as a consumer I can make a difference to how responsibly a company behaves [\%]

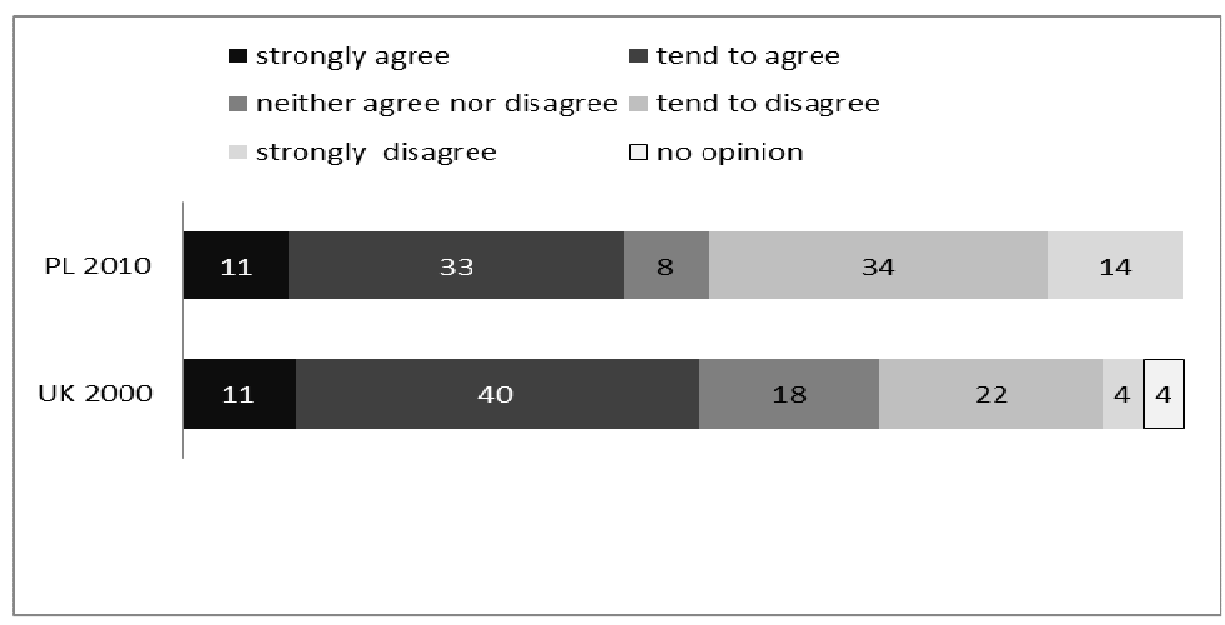

Source: developed by the author based own research R. M. Worcester, Ethical Consumerism Research, conducted for the Co-operative Bank, May 2000.

When the greatest obstacles to ethical consumerism as reported by Polish and British consumers are compared, then in both countries lack of knowledge and lack of information come to the fore (problems with finding out which products are made by responsible producers). Polish consumers additionally pointed to their limited trust, or its lack, in firms' declarations that they are responsible organizations $(22.4 \%$ of the respondents) and immediately afterwards to higher prices of products made by responsible manufacturers 
(20\%). In the UK surveys prices as an obstacle to the development of ethical consumerism were ranked last. Polish consumers also frequently indicated their problems with purchasing such products $(10.4 \%)$.

Globalization processes spreading via communications, advertising, marketing, trade, investment, and the media, and additionally supported by the growing use of advanced technologies has entrained a social and cultural homogenization on an equally worldwide scale. As a result, the new consumers constitute a class of people who often have more in common with their counterparts in other countries than with their fellow citizens. They share lifestyles, outlooks, and aspirations ((Myers N., Kent J. 2004. p 114). If Polish economy keeps growing at its present pace, Polish consumers become more and more eco-conscious, the NGOs and consumer movements continue to expand their activities, then the differences between the behaviours and attitudes of Polish and Western European consumers towards ecological and ethical issues can be expected to blur gradually.

\section{Typology of Polish consumers in respect of their sensitivity to ethical and environmental issues}

An overview of the Western European literature shows that globally increasing ecological and social awareness is one of the most distinct trends in consumption that has been observed in the recent years. (Alter Eco 2005, Ipsos MORI 2009, Global Lifestyle of Health...2008, Mirvis 2008, Cone 2008, The Ethical Consumerism 2007, 2008, 2009, 2010, Organic Exchange 2009) Consumers' behaviours and attitudes in the market for "socially responsible products"7 are becoming more and more important in Polish economy as well.

The aforementioned survey of Polish consumers which was enhanced with the findings provided by the analysis of secondary information sources allowed dividing them into typological groups that were homogenous in respect

\footnotetext{
${ }^{7}$ Produced by manufacturers respecting the natural environment and fundamental ethical principles (Myers N., Kent J. 2004. p. 114).
} 
of their sensitivity to various aspects of ecology and ethics ${ }^{8}$. The typology development process started with defining its criteria. The basic criterion was consumers' attitudes to ecological and ethical issues. Specific manifestations of their market behaviours, such as:

- active search for information about the ecological and ethical aspects of firms' activities;

- refraining from purchases of products offered by firms that are considered unethical (damaging the environment, abusing their workers, etc.);

- feeling guilty when someone happens to purchase products made by unethical firms;

- discussions about firms' conduct within a circle of friends;

- recommending products made by ethical firms to other people;

- involvement in campaigns promoting responsible consumption or fair trade;

- households recycling their waste;

- supporting local sellers and suppliers by doing shopping in the local shops;

- were used as additional criteria.

All the criteria were used then to define homogeneous types of consumers. To this end, an exploratory factor analysis was employed ${ }^{9}$ and correlation coefficients between particular variables were calculated.

\footnotetext{
${ }^{8}$ Consumers are a very heterogeneous population. This diversity results from individuals' having different psychographic, sociological, cultural, economic and other characteristics and from the fact that they show different market behaviours, choose different ways to find information and meet the needs, have different risk perception, etc. All these factors together impede the description of consumers and their behaviours. An instrument that is extremely helpful in overcoming the problem is consumer typology produced using particular research and analytical techniques. Typology can be developed by means of a so-called multivariate analysis that arranges and logically orders the elements of a given set, as well as comparing their characteristics with those of elements taken to represent types within a given set. Thus, typology allows identifying and describing these consumers' characteristics that shape typical characteristics of demand. In this sense, it offers many pieces of useful information on consumers' needs and preferences. See: (Kieżel 2010, pp. 190-198), (Smyczek, Sowa 2005, pp. 29-40).

${ }^{9}$ The exploratory factor analysis is applied, when correlated questions constituting a single dimension called a factor are sought, without making use of a priori created assumptions. This type of data analysis is useful for exploring data structures. One the other hand, if a particular structure and a number of factors have been determined a priori in line with some earlier theoretical assumptions, this variant of the analysis is called a confirmatory factor analysis (Bedyńska., Brzesińska 2007, p. 137), (Zakrzewska 1994, pp. 40-47).
} 
Table 3. Characteristics of the correlation matrix

\begin{tabular}{|l|l|c|}
\hline \multicolumn{2}{|c|}{ Statistic name } & Statistic value \\
\hline \multirow{2}{*}{ KMO measure of sampling adequacy } & 0.867 \\
\hline \multirow{3}{*}{ Bartlett's test of sphericity } & approximated chi-square & 2318.467 \\
\cline { 2 - 3 } & d.f. & 36 \\
\cline { 2 - 3 } & significance & 0.000 \\
\hline
\end{tabular}

Source: calculated by the author with SPSS software.

The table shows that the KMO measure's value is high, so the factor analysis model ${ }^{10}$ used for data analysis was selected well. The Bartlett's test shows the same. The next part of the analysis was performed using the principal component method ${ }^{11}$.

In the first step, varimax orthogonal rotation was applied to factor loadings. This technique makes it easier to interpret the results obtained, as it minimizes the number of variables that are needed to explain a given variable. To name the new variables (i.e. principal components), those having the greatest factor loadings with respect to component variables were isolated. Based on the scree test, eigenvalues and variance percentage, two major factors, i.e. 2 types of consumers, were selected for further analysis.

The analysis demonstrated that consumer behaviours could be grouped into two separate dimensions that also characterised some types of consumers (see tab. 4).

\footnotetext{
${ }^{10}$ The KMO measure of sampling adequacy is a ratio between the correlation of variables and their partial correlation. A KMO measure ranging from 0 to 1 indicates the degree of variable correlation. If it is lower than 0.6, then the data should not be used for factor analysis (Wieczorkowska, Wierzbiński 2007, p. 322). Kaiser proposes the following ratings of KMO values: 0.9-very high, 0.8-high, 0.7- medium, 0.6- moderate, <0.5- very low. (Stanisz 2007, p. 218) (Bedyńska., Brzezińska 2007, p. 141).

${ }^{11}$ This analysis allows transforming a given set of correlated characteristics (variables) into a new set of characteristics (otherwise principal components) that are not correlated, which is comparable with the initial system. Hence, a principal component analysis helps simplify data structures.
} 
Table 4. Rotated component matrix

\begin{tabular}{|l|c|c|}
\hline \multirow{2}{*}{ In the last 12 months, how often have you... } & \multicolumn{2}{|c|}{ Component } \\
\cline { 2 - 3 } & prosumer ethics & $\begin{array}{c}\text { everyday } \\
\text { practices }\end{array}$ \\
\hline Actively sought information on a company's behaviour/ policies & .794 & \\
\hline Avoided a product or service on a company's behaviour & .780 & \\
\hline Felt guilty about an unethical purchase & .756 & \\
\hline Recommended a company because of its responsible reputation & .703 & \\
\hline Chosen a product or service on a company's behaviour & 693 & \\
\hline Talked to friends/ family about a company's behaviour & .566 & \\
\hline Actively campaigned about an environmental/ social issue & 502 & \\
\hline Household waste recycled & & .745 \\
\hline Bought to support local shops/ suppliers & & .735 \\
\hline Percentage of voariance explained & 41.6 & 12.5 \\
\hline
\end{tabular}

$\mathrm{KMO}=0.867$. Rotation method - varimax with Keiser normalization.

Source: calculated by the author with SPSS software.

The first dimension can be called prosumer ethics and the second one everyday practices. Prosumer ethics involves behaviours such as intended purchases of products selected based on person's knowledge of the brand; rejection of products made by firms that are deemed unethical, being remorseful when such products are bought; discussions about firms' ethics with friends, recommending ethical firms' products to other people, as well as involvement in campaigns promoting responsible consumption or fair-trade concepts.

The second dimension encompasses behaviours such as daily recycling of waste and buying from local shops; these daily routines are not necessarily connected with consumers' ethical and environmental awareness. 
Table 5. Average values on a scale of 1 to 5 and standard deviations for the analysed variables

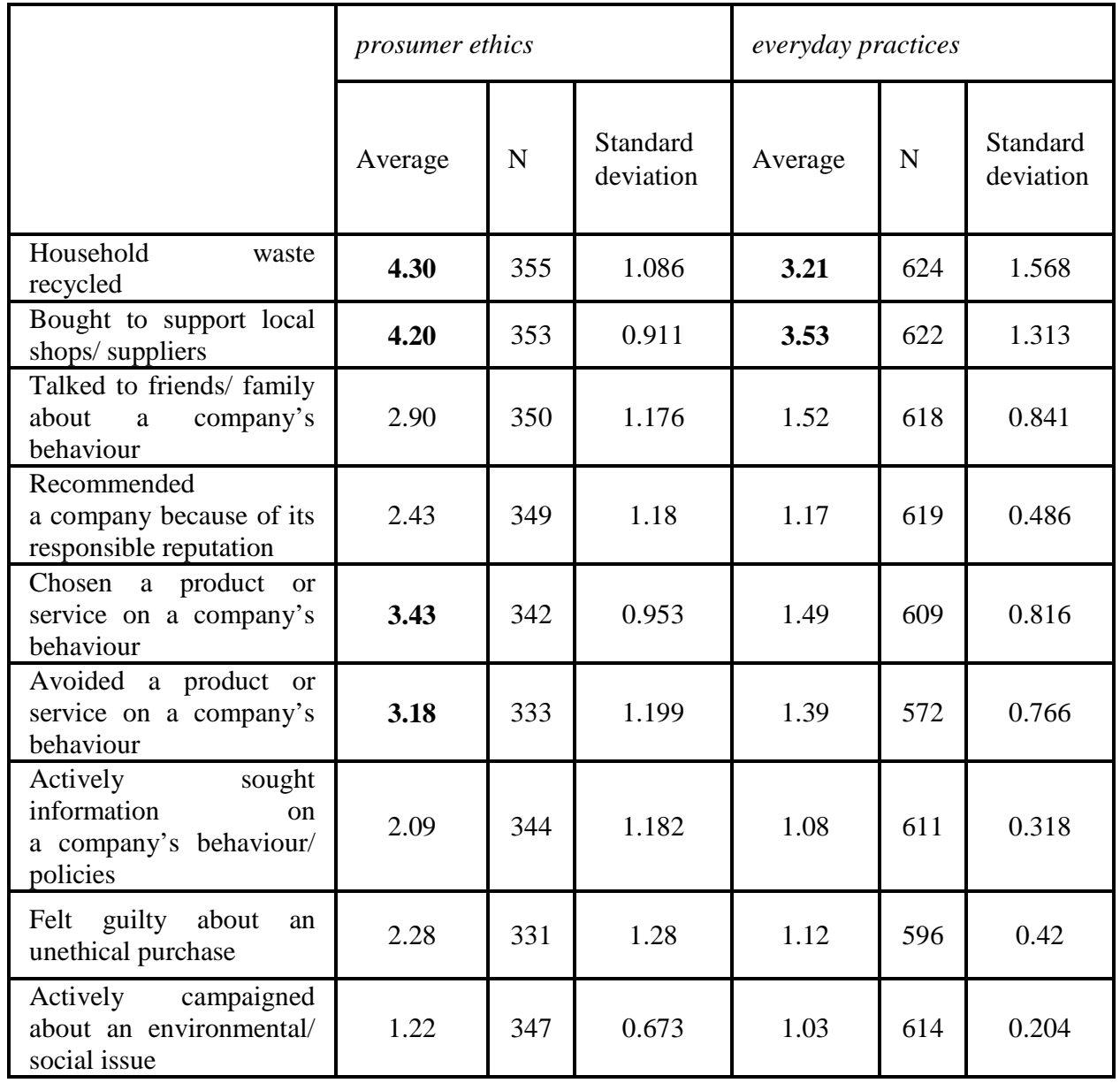

Source: calculated by the author with SPSS software.

Analysing data in table 5 we find that the prosumer behaviour of Polish consumers clearly concentrates on the ,essential" practices, such as waste recycling, supporting local businesses and intended purchases of products made by environmentally-friendly and ethical firms. At the same time, Polish prosumers tend to rejects products offered by firms deemed unethical.

Behaviours that the second type of consumers displays more often than „from time to time" do not go beyond waste recycling and support for local entrepreneurs (Chart 3). 
Chart 3. Consumer behaviour (average values on a scale from 1 to 5)

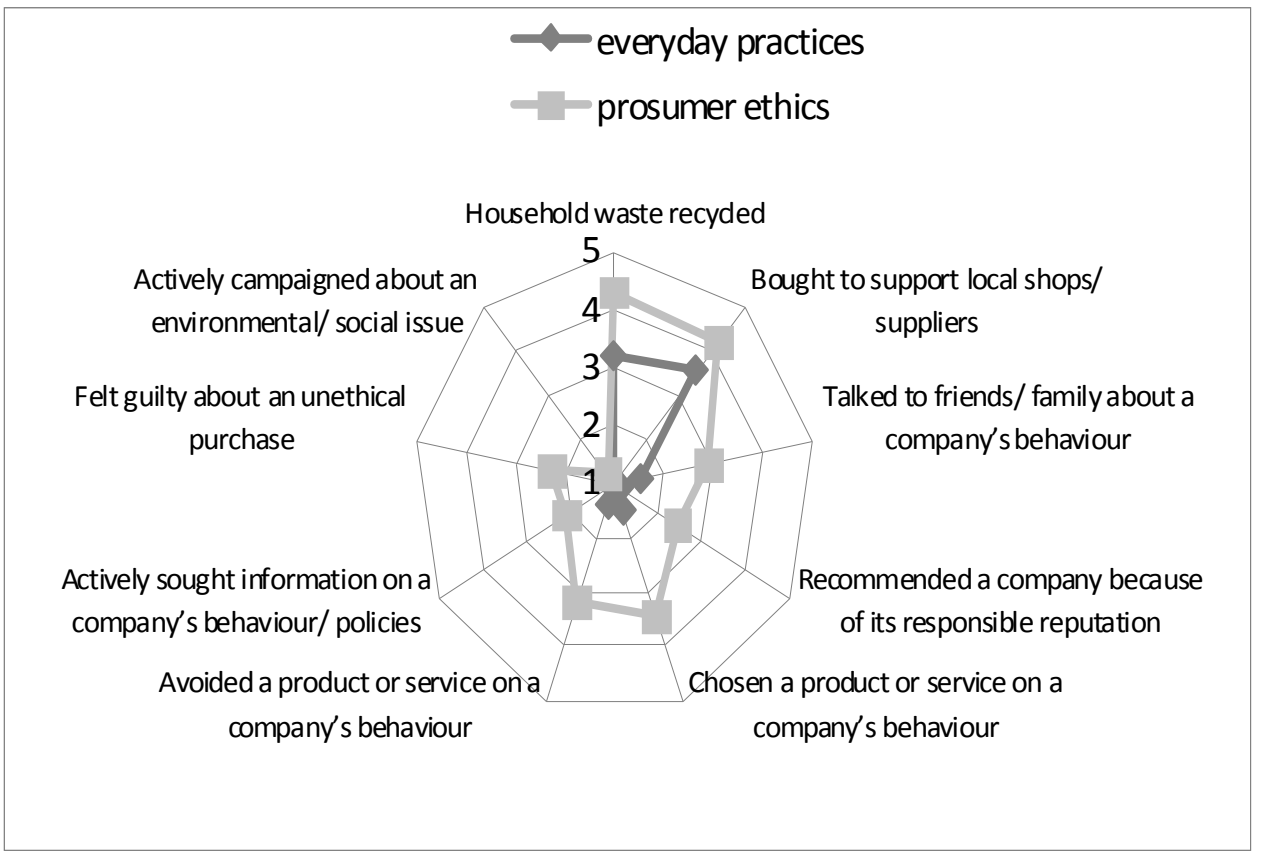

Source: developed by the author based on research results.

Another important stage in the analysis was identification of the selected types of consumers' shares in the studied population (see table 6).

Table 6. Particular types of consumers as shares of total population

\begin{tabular}{|l|c|c|}
\hline \multicolumn{1}{|c|}{ Consumer typology } & $\mathrm{N}$ & $\%$ \\
\hline Prosumer ethics & 355 & $36.1 \%$ \\
\hline Everyday practices & 626 & $63.9 \%$ \\
\hline Total & 981 & $100.0 \%$ \\
\hline
\end{tabular}

Source: calculated by the author.

Prosumers, i.e. consumers who consciously select products based on their knowledge about the firm and its brand and avoid products made by organizations that are considered unethical, who feel guilty buying such firms' products, who discuss business ethics with their families and friends and pursue practices that can be called essential (waste recycling) constituted $36.1 \%$ of the respondents. The other $63.9 \%$ were persons who did none of the things attributed to prosumer behaviour. 
Given that in the West European countries the aforementioned LOHAS consumers represent on average ca. $20 \%$ of the population (Global Lifestyle... 2008 ), the rate of $36 \%$ may seem surprisingly high. However, a more detailed analysis of the results (see table 7) shows that the average value of the index is 2.16 (1 meaning that the respondent never takes any pro-ethical or proenvironmental actions and 5 that they habitually get involved in such actions). The median value of the scale is 3 .

Table 7. Index of pro-ethical and pro-ecological behaviours

\begin{tabular}{|l|c|c|c|}
\hline \multirow{2}{*}{} & \multicolumn{3}{|c|}{ Index of pro-ethical and pro-ecological behaviour } \\
\cline { 2 - 4 } & Average & $\mathrm{N}$ & Standard deviation \\
\hline Prosumer ethics & 2,8977 & 355 & .50128 \\
\hline Everyday practices & 1,7447 & 626 & .35818 \\
\hline Total & 2,1615 & 981 & .69261 \\
\hline Median & 2,0000 & 981 & -- \\
\hline Modal value & 1,89 & 981 & -- \\
\hline First quartile (25) & 1,6667 & 981 & -- \\
\hline Second quartile (50) & 2,0000 & 981 & -- \\
\hline Third quartile (75) & 2,5556 & 981 & -- \\
\hline
\end{tabular}

Source: calculated by the author.

The value of the index is greater for respondents categorised as prosumers, but even in this group it is below the mid-point of the scale. If the respondents were arranged to follow ascending values of the index, then the median would be 2, a one fourth of the respondents would score less than 1.66 points and three-fourths less than 2.55 points. The most frequently occurring value is 1.8 .

\section{Conclusion}

1. Basically, Western and Eastern Europeans express very similar expectations of firms' ethical and environmentally-friendly behaviour. A study of their purchasing decisions shows, though, that the West and the East of Europe are much more at variance than the consumers' broad declarations show. Eastern Europeans are the least concerned about whether the product they purchase has negatively impacted workers or whether its environmental footprint is minimal. Support for fair-trade products nowadays is also largely concentrated in Western Europe. 
2. Comparing consumers' attitudes to responsible consumption in Poland being one of the "new consumer countries" and in the long-rich UK, we find the following:

- The greatest differences between the two countries can be seen for behaviours requiring the strongest activity and conscious involvement of consumers (e.g. campaigns promoting responsible consumption, intentional purchases of "socially responsible products" or recommending such products to family members and friends). Polish consumers were rated much less favourably than British consumers in both 1999 and 2010.

- There is also a group of behaviours indicating that consumers respect only some aspects of ethical buying, requiring somewhat weaker involvement (e.g. seeking information about firms' behaviour, avoiding products or services provided by firms that are deemed unethical). In this respect, Polish consumers are today where the UK consumers were a decade ago.

- The smallest differences between Polish and West European consumers can be found for behaviours that one might call essential practices (waste recycling, supporting domestic producers by doing one's shopping in the local shop). In this case, Polish consumers are rated the same or slightly better than their British counterparts.

3. The multivariate analysis of the data divided Polish consumers into typological groups that were homogenous in respect of sensitivity to various ethical and environmental issues. The analysis confirmed that Polish consumers were the most active in the area called "essential" or everyday practices.

4. The tendency towards ecological and ethical consumption is definitely less distinct in Poland than in Western Europe. It is likely, though, that the progressing globalization and social and cultural homogenization which is taking place on a worldwide scale, on one hand, and the continuing present rate of growth of Polish economy, growing consumers' awareness and increasing activity of consumer movements in Poland, on the other, will gradually make the differences blur in years ahead. 
Table 1. The New Consumers in 2000 and 2010

\begin{tabular}{|c|c|c|c|c|c|c|c|c|c|c|c|}
\hline Country & $\begin{array}{c}\text { GNI } \\
2002, \\
\text { PPP\$ } \\
\text { billions }\end{array}$ & $\begin{array}{c}\text { Conversion } \\
\$ 1 / \mathrm{PPP} \$ \\
2002\end{array}$ & $\begin{array}{l}\text { Purchasing } \\
\text { power } \\
2002 \text {, as \% } \\
\text { of GNI }\end{array}$ & \begin{tabular}{|c|} 
Purchasing \\
power \\
2002, \\
PPP\$ billions
\end{tabular} & $\begin{array}{c}\text { Economic } \\
\text { growth } \\
\text { projected } \\
2003-2010 \%\end{array}$ & $\begin{array}{c}\text { GNI } \\
\text { 2010 PPP\$ } \\
\text { billions }\end{array}$ & $\begin{array}{c}\text { Purchasing } \\
\text { power } \\
2010, \\
\text { PPP\$ } \\
\text { billions } \\
\end{array}$ & \begin{tabular}{|c|} 
New \\
consumers \\
2000 (and $\%$ \\
of \\
population) \\
\end{tabular} & $\begin{array}{c}\text { New } \\
\text { consumers } \\
2010 \text { (and \% } \\
\text { of } \\
\text { population) } \\
\end{array}$ & $\begin{array}{c}\text { New consumers } \\
\text { purchasing } \\
\text { power } \\
2000, \\
\text { PPP } \$ \text { billions } \\
\end{array}$ & \begin{tabular}{|c} 
New consumers \\
purchasing \\
power \\
2010, \\
PPP\$ billions \\
\end{tabular} \\
\hline China & 5649 & 4.67 & 50 & 2807 & 7.0 & 9706 & 4824 & $303(24)$ & $615(45)$ & 1267 & \begin{tabular}{|l|}
3535 \\
\end{tabular} \\
\hline India & 2685 & 5.35 & 68 & 1817 & 6.0 & 4279 & 2897 & $132(13)$ & $210(18)$ & 609 & 1346 \\
\hline South Korea & 785 & 1.66 & 61 & 476 & 5.6 & 1214 & 736 & $45(96)$ & $48.5(97)$ & 502 & 733 \\
\hline Philippines & 342 & 4.20 & 65 & 224 & 4.6 & 490 & 320 & $33(43)$ & $36(40)$ & 150 & 232 \\
\hline Indonesia & 631 & 4.21 & 75 & 470 & 4.1 & 870 & 650 & $63(30)$ & $67(28)$ & 288 & 355 \\
\hline Malaysia & 201 & 2.34 & 49 & 98 & 4.2 & 279 & 136 & $12(53)$ & $15(57)$ & 79 & 118 \\
\hline Thailand & 412 & 3.37 & 58 & 240 & 4.7 & 595 & 347 & $32(53)$ & $42(60)$ & 179 & 291 \\
\hline Pakistan & 280 & 4.73 & 77 & 215 & 4.1 & 386 & 296 & $17(12)$ & $22(12)$ & 62 & 94 \\
\hline Iran & 416 & 3.71 & 43 & 178 & 4.0 & 569 & 244 & $27(42)$ & $49(60)$ & 136 & 204 \\
\hline Saudi Arabia & 246 & 1.36 & 46 & 112 & 3.1 & 314 & 143 & $13(61)$ & $17(61)$ & 78 & 124 \\
\hline South Africa & 431 & 3.80 & 60 & 260 & 2.4 & 521 & 314 & $17(40)$ & $22(49)$ & 202 & 276 \\
\hline Brazil & 1265 & 2.54 & 58 & 738 & 3.5 & 1666 & 973 & $75(44)$ & $88(46)$ & 641 & 840 \\
\hline Argentina & 377 & 2.45 & 76 & 288 & 2.6 & 463 & 353 & $31(84)$ & $33(80)$ & 314 & 337 \\
\hline Venezuela & 127 & 1.24 & 73 & 93 & 4.1 & 175 & 127 & $13(56)$ & $15(50)$ & 87 & 105 \\
\hline Colombia & 257 & 3.21 & 64 & 164 & 3.4 & 336 & 215 & 19(45) & 21(43) & 136 & 175 \\
\hline Mexico & 862 & 1.45 & 79 & 681 & 4.0 & 1180 & 928 & $68(69)$ & $79(70)$ & 624 & 867 \\
\hline Turkey & 426 & 2.45 & 67 & 285 & 3.2 & 548 & 366 & $45(69)$ & $46(61)$ & 265 & 309 \\
\hline Poland & 392 & 2.22 & 85 & 334 & 3.2 & 504 & 430 & $34(86)$ & $36(96)$ & 206 & 427 \\
\hline Ukraine & 228 & 6.04 & 67 & 152 & 4.8 & 332 & 222 & $12(23)$ & $32(70)$ & 44 & 188 \\
\hline Russia & 1125 & 3.65 & 61 & 687 & 4.0 & 1540 & 942 & $68(47)$ & $96(70)$ & 436 & 866 \\
\hline Totals & 17,137 & 3.30 & 60 & 10,319 & - & 25,968 & 15,463 & $1056(29)$ & 1589(39) & 6305 & 11,422 \\
\hline USA & 10,110 & 1.00 & 70 & 7077 & 3.4 & 13,210 & 9247 & - & - & 6728 & 9257 \\
\hline World & 46,916 & 1.49 & 60 & 28,103 & 3.3 & 60,830 & 36,438 & - & - & 27,657 & 36,438 \\
\hline
\end{tabular}

Source: Myers, Norman; Kent, Jennifer. New Consumers: The Influence of Affluence on the Environment. Washington, DC, USA: Island Press, 2004 p. 113. 


\section{References}

Alter Eco, (2005), 2002-2005 Les consommateurs français et le Commerce Équitable, http://www.altereco.com/_data/documents\%20PDF/Etude\%20avril\%202005.pdf, (access: 16.1.2010)

Bedyńska S., Brzesińska A. (2007), Statystyczny drogowskaz. Praktyczny poradnik analizy danych $w$ naukach społecznych na przykładach $z$ psychologii. Wydawnictwo SWPS Academica, Warszawa

Bhandarkar M., Alvarez-Rivero T. (2007), From supply chains to value chains: A spotlight on CSR in: Industrial Development for the 21st Century: Sustainable Development Perspectives UN, New York

Bywalec Cz. (2007), Konsumpcja w teorii i praktyce gospodarowania, PWN, Warszawa

Can You Hear Me, Ipsos MORI 2009,

http://www.ipsos-mori.com/DownloadPublication/1287_reputation-newsletter-can-you-hearme.pdf, (access: 16.1.2010)

Carbone V., Moatti V.,Greening the Supply Chain: Preliminary Results of a Global Survey, Supply Chain Forum An International Journal Vol. 9 - N² - 2008

Corporate Ethics and Fair Trading. A Nielsen Global Consumer Report, October 2008, http://tr.nielsen.com/site/documents/CSR_Fairtrade_global_reportOctober08.pdf

de Brito M., Carbone, V., \& Meunier, C. (2008), Towards a sustainable fashion retail supply chain in Europe: Organisation and performance, International Journal of Production and Economics, 114, 534-553

Global Lifestyle of Health and Sustainability. An overview on the growing global market and consumer base for sustainable products and services August 2008, Moxie Design Group Limited,http://www.nzbcsd.org.nz/_attachments/GLOHAS_international_publication_FINAL.pdf (access: 10 March .2011)

Janoś-Kresło M., Mróz B. (2006), Konsument i konsumpcja we wspótczesnej gospodarce, SGH, Warszawa

Kieżel E. (2010), Konsument i jego zachowania na rynku europejskim, PWE, Warszawa

Mirvis P. H., Can You Buy CSR? California Management Review Vol. 51, No. 1 Fall 2008 Cmr.Berkeley.Edu, s. 109

Moore S. B, Ausley L.W. (2004), Systems thinking and green chemistry in the textile industry: concepts, technologies and benefits, Journal of Cleaner Production 12 585-601

Myers N., Kent J. (2004) New Consumers : The Influence of Affluence on the Environment, Washington, DC, USA: Island Press

Organic Exchange - Organic Cotton Market Report 2009, www.organicexchange.org 
Ratnakar Adhikari and Yumiko Yamamoto (2007) The textile and clothing Industry: Adjusting to the post-quota world, in: Industrial Development for the 21st Century: Sustainable Development Perspectives UN, New York, 2007, p. 205

Smyczek S., Sowa I. (2005), Konsument na rynku. Zachowania, modele, aplikacje, Difin, Warszawa

Stanisz A. (2007), Przystępny kurs statystyki, tom 3, Kraków

Ten Years of Ethical Consumerism: 1999-2008, The Co-operative Bank, with additional research by the Ethical Consumer Research Association (ECRA), Available from www.goodwithmoney.co.uk/ethicalconsumerismreport (23 Feb. 2010)

The Cone Cause Evolution \& Environmental Survey (2008), www.coneinc.com

The Ethical Consumerism Report (2007), the Co-operative Bank, with additional research by the Ethical Consumer Research Association (ECRA),

http://www.co-operativebank.co.uk/images/pdf/ethical_consumer_report_2007.pdf

The Ethical Consumerism Report (2008), the Co-operative Bank, with additional research by the Ethical Consumer Research Association (ECRA),

http://www.ethicalconsumer.org/Portals/0/Downloads/ETHICAL\%20CONSUMER\%20REPORT. pdf

The Ethical Consumerism Report (2009), the Co-operative Bank, with additional research by the Ethical Consumer Research Association (ECRA)

The Ethical Consumerism Report 2010. Ethical Shopping Through the Downturn, The Cooperative Bank, with additional research by the Ethical Consumer Research Association (ECRA), www.goodwithmoney.co.uk/ethicalconsumerismreport (access: 9 March 2011)

Wieczorkowska G., Wierzbiński J. (2007), Statystyka, Analiza badań społecznych, WN SCHOLAR, Warszawa 2007

Zakrzewska M. (1994), Analiza czynnikowa w budowaniu i sprawdzaniu modeli psychologicznych, Wydawnictwo Naukowe Uniwersytetu im. Adama Mickiewicza, Poznań

\section{Streszczenie}

\section{PERSPEKTYWY ROZWOJU EKOLOGICZNEJ I ETYCZNEJ KONSUMPCJI W POLSCE NA TLE KRAJÓW ZACHODNIO-EUROPEJSKICH}

Przeglad literatury zachodnio-europejskiej pozwala stwierdzić, że jednym $z$ najbardziej zauważalnych trendów $w$ sferze konsumpcji w ostatnich latach jest coraz większa świadomość ekologiczna i społeczna $w$ wymiarze globalnym. Problematyka 
zachowań $i$ postaw konsumentów wobec produktów "spotecznie odpowiedzialnych" nabiera coraz większego znaczenia także $w$ polskiej gospodarce. Celem artykutu jest ocena perspektyw rozwoju etyczneji ekologicznej konsumpcji w Polsce na tle krajów zachodnio-europejskich. Analize porównawczq prowadzono bazując na źródtach wtórych jak i badaniach pierwotnych realizowanych na reprezentatywnej próbie losowej dorostych mieszkańców Polski. W oparciu o analizę czynnikowa, a dokładniej metodę analizy głównych składowych, dokonano także podziału polskich konsumentów na jednorodne grupy typologiczne pod względem ich wrażliwości na różne aspekty zwiazane z ekologia i etyka. 